\title{
Influence of plantation of a shelter-belt on component of organic carbon in the Taklimakan desert over last decade
}

\author{
Jin Zhengzhong*, Wang Yingju, and Lei Jiaqiang \\ Xinjiang Institute of Ecology and Geography, Chinese Academy of Sciences, Urumqi, 830011, China
}

\begin{abstract}
The soils were collected from the Taklimakan Desert Highway shelter-belt with different planting years in Xinjiang, northwest of China. The soil organic carbon stork ( $\left.\mathrm{SOC}_{\text {stork}}\right)$ in each layers. By chemical and physical pretreatment, we measured four carbon passive organic carbons, i.e., microaggregates organic carbon $\left(\mathrm{OC}_{\mathrm{MIA}}\right)$, humus organic carbon $\left(\mathrm{OC}_{\mathrm{HS}}\right)$, carbon resistance to oxidation $(\mathrm{OC} \mathrm{NaClO})$ and acid hydrolysis $\left(\mathrm{OC}_{\mathrm{HCl}}\right)$. The results showed that the $\mathrm{OC}$ and $\mathrm{SOC}_{\text {stork }}$ was decreased with soil depth mainly in $0-50 \mathrm{~cm}$. The artificial vegetation have more influence on TOC, OCMIA and $\mathrm{OC}_{\mathrm{HS}}$ than $\mathrm{OC}_{\mathrm{NaClO}}$ and $\mathrm{OC}_{\mathrm{HCl}}$. The Tamarix chinensis shelter-belt is the most helpful for carbon sequestration in sandy soil and stabilization in surface layer than Calligonum mongolicunl and Haloxylon ammodendron.
\end{abstract}

\section{Introduction}

The buildup of an artificial shelter-belt can bring extensive changes to the local soil properties [1]. Soil organic material (SOM) is closely associated with soil development processes. In a desert environment, after artificial shelter-belt was planted, the litter began to enter into soil, can provide nutrition for soil microorganisms, promoting the decomposition of soil organic carbon and forming organic matter [2]. Soil organic carbon (SOC) is a major component of SOM. Therefore, research on SOC changes along with the increase of year of the artificial vegetation plantation can preliminary clarify the law of organic carbon dynamics of sandy soil under the influence of artificial vegetation.

SOC includes plant, animal and microbial residues in all stages of decomposition and can be divided into active, intermediate and passive pools based on the turnover rate of different compounds [3]. Passive $\mathrm{C}$ pool is more stable to stay in soil for a long time, and research on passive carbon pool along with the change of years of artificial vegetation plantation can reflect the dynamic law of soil organic carbon [4].

Humic substances stabilized by humication processes are considered to be refractory to decomposition, thus belonging to the passive SOM pool [5]. And mineral weathering and mineral-organic chelate migration are related to humic substance characteristics [6], so it can be considered as an indicator of SOC dynamics during soil development.

The ability of resistance to decomposition of organic molecules increases their own stability [7], extend turnover time, be helpful for carbon accumulation. For example, organic molecules with resistance to hydrolysis are also resistant to soil enzymes, are therefore also more biologically stable [8]. In an extensive review of $\mathrm{HCl}$ hydrolysis, concluded that non-hydrolyzable C represented 30 to $80 \%$ of total SOC, had an average mean residence time 1200 year greater than that of the total SOC [9]. Acid hydrolysis effectively removes carbohydrate and protein materials by disruption of hydrolytic bonding, leaving the more biological recalcitrant alkyl and aryl materials [10], belonging to the chemical passive SOM pool too.

Previous studies showed that the SOM content and humus organic carbon in soil surface $(10 \mathrm{~cm})$ layer increased with the planting years of the forest [11], the micro-aggregate organic carbon had no obvious change [12]. The dynamic changes of organic carbon resistance to hydrolysis and oxidation, carbon stork after vegetation planted didn't see public reporting. But the conclusion is based on qualitative research, rather than quantitative research. To sum up, this paper select shelter-belt of the Tarim desert highway with different planting years, by measuring soil passive carbon fractions to illustrate the influence of shelter-belt on soil organic carbon dynamics during the process of development of sandy soil, can provide information for the carbon balance estimation for arid areas.

\section{Materials and methods}

\subsection{Area description}

The study area is located in the Tarim Oil Field of the Taklimakan Desert in Xinjiang, northwest of China. The annual average air temperature is $12.4{ }^{\circ} \mathrm{C}$ for last 20 years. The temperature on the surface of sand can reach as high as $75.3^{\circ} \mathrm{C}$ during summer. The average annual rainfall is $24.6 \mathrm{~mm}$ and the average annual evaporation is $3638.6 \mathrm{~mm}$. The annual days that intense wind and sand

\footnotetext{
Corresponding author: jzz3501@126.com
} 
happened are more than $130 \mathrm{~d}$, and hazards of sand are very serious.

\subsection{Soil sampling}

Soil samples were collected along the Taklimakan Desert Highway Shelter-belt. The construction tree species are three shrubs named Calligonum mongolicunl (C.m.), Tamarix chinensis (T.c.) and Haloxylon ammodendron (H.a.), which are resistance to drought, salt and alkali. The plant spacing is $1 \mathrm{~m} \times 1 \mathrm{~m}$. The width of the shelter-belt is $72-78 \mathrm{~m}$. The type of the soil is aeolian sandy soil. The shelter-belt was drip-irrigated with saline water.

The five plots were comprised of shrubs with different stand age $(5,7,10,13$, and 16 with the planting time of 2006, 2004, 2001, 1998, and 1995 respectively). At each plot, we selected three plant randomly which Looks like each other, can reflect the characteristics of the samples in all the plants. Collected three $1 \mathrm{~kg}$ subsamples from the $0-10 \mathrm{~cm}, 10-20 \mathrm{~cm}, 20-35 \mathrm{~cm}, 35-50$ $\mathrm{cm}, 50-70 \mathrm{~cm}, 70-100 \mathrm{~cm}, 100-150 \mathrm{~cm}, 150-200 \mathrm{~cm}$ depth layers respectively, $50 \mathrm{~cm}$ far from the roots of plant, and then mixed with one sample. The soil samples were then air-dried for laboratory analysis.

\subsection{Soil analysis}

We collected soil sample from the surface layer (0-10 $\mathrm{cm})$ for the extraction the passive organic carbon. The method used for soil aggregate separation was dry sieving method, and then determined by dichromate oxidation method [13] for TOC and micro-aggregates organic carbon $\left(\mathrm{OC}_{\mathrm{MIA}}\right)$.

Humus was determined by a $\mathrm{NaOH}-\mathrm{Na}_{4} \mathrm{P}_{2} \mathrm{O}_{7}$ extraction-separation technique according to Zhang et al. (2010) [11]. $10 \mathrm{~g}$ soil $(\mathrm{d}<0.25 \mathrm{~mm})$ was extracted by $\mathrm{NaOH}(0.1 \mathrm{M})-\mathrm{Na}_{4} \mathrm{P}_{2} \mathrm{O}_{7}(0.1 \mathrm{M})$ alkali mixture solution (10g soil/ $200 \mathrm{ML}$ extraction) for $20 \mathrm{~h}$, and filtered. The soils dried at constant temperature $60^{\circ} \mathrm{C}$ for three weeks and then determined by dichromate oxidation method [13] for humus organic carbon $\left(\mathrm{OC}_{\mathrm{HS}}\right)$.

The organic carbon fraction resistant to oxidation was extracted according to Siregar et al. (2005) with minor modifications [14]. The organic carbon fraction resistant to hydrolysis $\left(\mathrm{OC}_{\mathrm{HCl}}\right)$ was extracted according to Paul et al. (1997) with minor modification [15].

The air-dried soils collected from 0-10, 10-20, 20-35, $35-50,50-70$ and $70-100 \mathrm{~cm}$ layers were sieved through $0.25 \mathrm{~mm}$ sieve; the soil organic carbon content was measured.

We used the following formula (Eq. (1)) for the calculation of SOC stock in $\mathrm{i}$ layer: (1)

$\mathrm{SOC}_{\mathrm{i}}, \quad$ Stork $=\mathrm{OC}_{\mathrm{i}} \times \mathrm{BD}_{\mathrm{i}} \times$ Depth $_{\mathrm{i}} \times 10$

Where, $\mathrm{SOC}_{\mathrm{i} \text {, stock }}$ is the soil OC stock $\left(\mathrm{g} \mathrm{C}^{-2} \mathrm{~m}^{-2}\right.$ in $\mathrm{i}$ layers $(\mathrm{i}=1,2,3 \ldots \ldots 6) ; \mathrm{OC}_{\mathrm{i}}$ was the organic carbon concentration $\left(\mathrm{g}^{\circ} \mathrm{kg}^{-1}\right)$ passed throw $0.25 \mathrm{~mm}$ sieves in the bulk soil of the i layer; BD was the bulk density of the i layer $\left(\mathrm{g} \cdot \mathrm{m}^{-3}\right)$, and Depth was the soil depth $(\mathrm{cm})$ of the i layer.

\subsection{Statistical analysis}

Effects of plantation year on soil organic stork and passive fractions were verified statistically using OneWay ANOVA analysis. Means were compared using new multiple range test (Duncan), and the relationships between different organic carbon fractions were analyzed with Pearson correlation coefficient. Difference was declared significant at $\alpha<0.05$. All analysis were conducted by SPSS16.0. Origin 8.0 were used to create the figures.

\section{Results}

\subsection{Dynamic changes of OC and $\mathrm{SOC}_{\text {stork }}$ with soil depth}

Table 1. The changes of OC with soil depth

\begin{tabular}{|c|c|c|c|c|c|c|}
\hline \multirow{2}{*}{$\begin{array}{l}\text { Plant } \\
\text { species }\end{array}$} & \multirow{2}{*}{$\begin{array}{c}\text { Soil } \\
\text { depth } \\
\text { (cm) }\end{array}$} & \multicolumn{5}{|c|}{ Planting years (a) } \\
\hline & & 5 & 7 & 10 & 13 & 16 \\
\hline \multirow{8}{*}{ H.a. } & $0-10$ & $1.7 \pm 0.4 \mathrm{a}$ & $0.9 \pm 0.2 \mathrm{ab}$ & $2.7 \pm 0.3 \mathrm{a}$ & $1.7 \pm 0.2 \mathrm{a}$ & $1.4 \pm 0.4 \mathrm{a}$ \\
\hline & $10-20$ & $1.6 \pm 0.0 \mathrm{a}$ & $1.2 \pm 0.3 \mathrm{a}$ & $2.2 \pm 0.2 \mathrm{ab}$ & $1.3 \pm 0.2 \mathrm{~b}$ & $0.8 \pm 0.0 \mathrm{a}$ \\
\hline & $20-35$ & $1.2 \pm 0.1 \mathrm{ab}$ & $0.9 \pm 0.2 \mathrm{ab}$ & $1.8 \pm 0.2 \mathrm{ab}$ & $1.1 \pm 0.1 \mathrm{~b}$ & $1.4 \pm 0.4 \mathrm{a}$ \\
\hline & $35-50$ & $1.0 \pm 0.1 \mathrm{bc}$ & $0.6 \pm 0.2 b$ & $1.5 \pm 0.2 \mathrm{~b}$ & $1.1 \pm 0.1 \mathrm{~b}$ & $0.9 \pm 0.2 \mathrm{a}$ \\
\hline & $50-70$ & $0.9 \pm 0.1 \mathrm{bc}$ & $0.6 \pm 0.1 \mathrm{~b}$ & $1.6 \pm 0.3 \mathrm{ab}$ & $1.0 \pm 0.1 \mathrm{~b}$ & $0.8 \pm 0.1 \mathrm{a}$ \\
\hline & $70-100$ & $0.8 \pm 0.1 \mathrm{bc}$ & $0.6 \pm 0.1 \mathrm{~b}$ & $1.6 \pm 0.7 \mathrm{ab}$ & $1.3 \pm 0.1 \mathrm{~b}$ & $1.4 \pm 0.3 \mathrm{a}$ \\
\hline & $100-150$ & $0.7 \pm 0.1 \mathrm{c}$ & $0.5 \pm 0.1 \mathrm{~b}$ & $1.8 \pm 0.4 \mathrm{ab}$ & $1.2 \pm 0.1 \mathrm{~b}$ & $0.8 \pm 0.1 \mathrm{a}$ \\
\hline & $150-200$ & $0.9 \pm 0.1 \mathrm{bc}$ & $0.6 \pm 0.1 \mathrm{~b}$ & $1.2 \pm 0.1 \mathrm{~b}$ & $1.1 \pm 0.1 \mathrm{~b}$ & $0.8 \pm 0.0 \mathrm{a}$ \\
\hline \multirow{8}{*}{ T.c. } & $0-10$ & $1.4 \pm 0.3 \mathrm{~b}$ & $1.6 \pm 0.2 \mathrm{a}$ & $1.5 \pm 0.1 \mathrm{a}$ & $2.2 \pm 0.4 \mathrm{a}$ & $2.3 \pm 0.4 \mathrm{a}$ \\
\hline & $10-20$ & $1.4 \pm 0.1 \mathrm{~b}$ & $1.1 \pm 0.2 \mathrm{a}$ & $1.3 \pm 0.1 \mathrm{ab}$ & $1.3 \pm 0.2 \mathrm{~b}$ & $2.1 \pm 0.1 \mathrm{a}$ \\
\hline & $20-35$ & $1.4 \pm 0.1 \mathrm{~b}$ & $1.1 \pm 0.2 \mathrm{a}$ & $1.5 \pm 0.2 \mathrm{a}$ & $1.2 \pm 0.3 \mathrm{~b}$ & $2.2 \pm 0.4 \mathrm{a}$ \\
\hline & $35-50$ & $1.5 \pm 0.2 \mathrm{~b}$ & $1.2 \pm 0.1 \mathrm{a}$ & $1.1 \pm 0.1 \mathrm{bc}$ & $1.2 \pm 0.1 \mathrm{~b}$ & $1.4 \pm 0.2 \mathrm{a}$ \\
\hline & $50-70$ & $1.4 \pm 0.1 \mathrm{~b}$ & $1.0 \pm 0.1 \mathrm{a}$ & $0.9 \pm 0.1 \mathrm{~cd}$ & $1.5 \pm 0.2 \mathrm{ab}$ & $1.5 \pm 0.4 \mathrm{a}$ \\
\hline & $70-100$ & $1.2 \pm 0.1 \mathrm{~b}$ & $1.3 \pm 0.4 \mathrm{a}$ & $0.8 \pm 0.1 \mathrm{~d}$ & $1.3 \pm 0.4 \mathrm{~b}$ & $1.4 \pm 0.3 \mathrm{a}$ \\
\hline & $100-150$ & $1.7 \pm 0.2 \mathrm{ab}$ & $1.1 \pm 0.2 \mathrm{a}$ & $0.8 \pm 0.0 \mathrm{~cd}$ & $1.3 \pm 0.2 \mathrm{~b}$ & $1.4 \pm 0.3 \mathrm{a}$ \\
\hline & $150-200$ & $2.3 \pm 0.4 \mathrm{a}$ & $1.0 \pm 0.2 \mathrm{a}$ & $0.8 \pm 0.1 \mathrm{~cd}$ & $1.5 \pm 0.2 \mathrm{ab}$ & $1.3 \pm 0.4 \mathrm{a}$ \\
\hline \multirow{8}{*}{ C.m. } & $0-10$ & $1.4 \pm 0.4 \mathrm{a}$ & $1.1 \pm 0.1 \mathrm{a}$ & $2.1 \pm 0.2 \mathrm{a}$ & $2.4 \pm 0.3 \mathrm{a}$ & $2.0 \pm 0.2 \mathrm{a}$ \\
\hline & $10-20$ & $1.2 \pm 0.2 \mathrm{a}$ & $0.8 \pm 0.1 \mathrm{a}$ & $1.5 \pm 0.2 \mathrm{~b}$ & $1.9 \pm 0.1 \mathrm{ab}$ & $1.8 \pm 0.2 \mathrm{a}$ \\
\hline & $20-35$ & $1.4 \pm 0.1 \mathrm{a}$ & $0.7 \pm 0.1 \mathrm{a}$ & $1.4 \pm 0.3 \mathrm{bc}$ & $1.9 \pm 0.4 \mathrm{ab}$ & $1.4 \pm 0.3 \mathrm{ab}$ \\
\hline & $35-50$ & $1.6 \pm 0.1 \mathrm{a}$ & $1.0 \pm 0.2 \mathrm{a}$ & $0.9 \pm 0.0 \mathrm{c}$ & $1.6 \pm 0.3 \mathrm{ab}$ & $1.1 \pm 0.2 b c$ \\
\hline & $50-70$ & $1.4 \pm 0.2 \mathrm{a}$ & $1.0 \pm 0.2 \mathrm{a}$ & $0.9 \pm 0.1 \mathrm{c}$ & $1.5 \pm 0.3 \mathrm{ab}$ & $0.8 \pm 0.1 \mathrm{c}$ \\
\hline & $70-100$ & $1.2 \pm 0.1 \mathrm{a}$ & $1.1 \pm 0.3 \mathrm{a}$ & $0.9 \pm 0.2 \mathrm{c}$ & $1.3 \pm 0.2 \mathrm{~b}$ & $0.8 \pm 0.1 \mathrm{c}$ \\
\hline & $100-150$ & $1.2 \pm 0.1 \mathrm{a}$ & $1.2 \pm 0.3 \mathrm{a}$ & $0.9 \pm 0.1 \mathrm{c}$ & $1.5 \pm 0.2 \mathrm{ab}$ & $1.1 \pm 0.2 b c$ \\
\hline & $150-200$ & $1.1 \pm 0.1 \mathrm{a}$ & $1.4 \pm 0.4 \mathrm{a}$ & $0.8 \pm 0.1 \mathrm{c}$ & $1.5 \pm 0.5 \mathrm{ab}$ & $0.7 \pm 0.1 \mathrm{c}$ \\
\hline
\end{tabular}

Note: $\mathrm{a}, \mathrm{b}$ and $\mathrm{c}$ represents the results of multiple comparisons.

The changes of soil OC with soil depth can be seen from Table 1. Mainly in $0-50 \mathrm{~cm}$, the content of H.a. (in 5 years), T.c.(in 10 years) and C.m. (in 10 and 16 years) decreased with soil depth, and didn't change obvious below that layer. The OC contents in surface layer is the highest. As for three kinds of plants, C.m have more 
influence on soil carbon content in vertical space than H.a.and T.c.

As can be seen from Table 2, soil OC $_{\text {stork }}$ decreased with depth mainly in $0-50 \mathrm{~cm}$, and only appeared in 10 and 16 years in C.m forest, and 5, 16 years in H.a. forest. Compared three kinds of plants, C.m. and H.a. have more influence on changes of $\mathrm{SOC}_{\text {stork }}$ in vertical space than T.c in early stages of the development of sand soil.

Table 2. Changes of $\mathrm{SOC}_{\text {stork }}$ with soil depth

\begin{tabular}{|c|c|c|c|c|c|c|}
\hline \multirow{2}{*}{$\begin{array}{l}\text { Plant } \\
\text { species }\end{array}$} & \multirow{2}{*}{$\begin{array}{c}\text { Soil } \\
\text { depth } \\
\text { (cm) }\end{array}$} & \multicolumn{5}{|c|}{ Planting years (a) } \\
\hline & & 5 & 7 & 10 & 13 & 16 \\
\hline \multirow{6}{*}{ H.a. } & $0-10$ & $217 \pm 43.0 \mathrm{a}$ & $125 \pm 27.5 \mathrm{a}$ & $349 \pm 45.4 \mathrm{a}$ & $233 \pm 33.1 \mathrm{a}$ & $253 \pm 13.3 \mathrm{a}$ \\
\hline & $10-20$ & $219 \pm 6.3 \mathrm{a}$ & $169 \pm 45.1 \mathrm{a}$ & $294 \pm+24.7 \mathrm{a}$ & $184 \pm 23.8 \mathrm{ab}$ & $216 \pm 29.5 \mathrm{a}$ \\
\hline & $20-35$ & $178 \pm 17.0 \mathrm{ab}$ & $141 \pm 24.6 \mathrm{a}$ & $256 \pm 19.9 \mathrm{a}$ & $168 \pm 22.1 \mathrm{ab}$ & $114 \pm 11.8 \mathrm{~b}$ \\
\hline & $35-50$ & $139 \pm 6.4 \mathrm{~b}$ & $89 \pm 23.6 \mathrm{a}$ & $236 \pm 23.4 \mathrm{a}$ & $161 \pm 16.1 \mathrm{~b}$ & $119 \pm 13.8 \mathrm{~b}$ \\
\hline & $50-70$ & $121 \pm 17.1 \mathrm{~b}$ & $86 \pm 14.3 \mathrm{a}$ & $249 \pm 50.0 \mathrm{a}$ & $137 \pm 1.9 \mathrm{~b}$ & $126 \pm 6.4 \mathrm{~b}$ \\
\hline & $70-100$ & $120 \pm 8.6 \mathrm{~b}$ & $85.2 \pm 10.1 \mathrm{a}$ & $251 \pm 120 \mathrm{a}$ & $195 \pm 13.9 \mathrm{ab}$ & $125 \pm 3.6 \mathrm{~b}$ \\
\hline \multirow{6}{*}{ T.c. } & 10 & $227 \pm 58.0 \mathrm{a}$ & $222 \pm 21.9 \mathrm{a}$ & $200 \pm 7.2 \mathrm{a}$ & $280 \pm 53.9 \mathrm{a}$ & $310 \pm 53.3 \mathrm{a}$ \\
\hline & $10-20$ & $219 \pm 12.2 \mathrm{a}$ & $163 \pm 22.0 \mathrm{a}$ & $173 \pm 8.4 \mathrm{a}$ & $192 \pm 32.9 \mathrm{a}$ & $297 \pm 9.1 \mathrm{a}$ \\
\hline & $20-35$ & $204 \pm 11.5 \mathrm{a}$ & $90.3 \pm 46.6 \mathrm{a}$ & $146 \pm 74.4 \mathrm{a}$ & $182 \pm 49.1 \mathrm{a}$ & $313 \pm 64.3 \mathrm{a}$ \\
\hline & $35-50$ & $222 \pm 21.8 \mathrm{a}$ & $176 \pm 5.01 \mathrm{a}$ & $115 \pm 57.8 \mathrm{a}$ & $188 \pm 15.3 \mathrm{a}$ & $197 \pm 27.7 \mathrm{a}$ \\
\hline & $50-70$ & $221 \pm 22.3 \mathrm{a}$ & $90.4 \pm 46.1 \mathrm{a}$ & $105 \pm 52.4 \mathrm{a}$ & $243 \pm 40.4 \mathrm{a}$ & $224 \pm 54.8 \mathrm{a}$ \\
\hline & $70-100$ & $186 \pm 14.1 \mathrm{a}$ & $202 \pm 67.6 \mathrm{a}$ & $111 \pm 19.1 \mathrm{a}$ & $209 \pm 61.5 \mathrm{a}$ & $201 \pm 43.9 \mathrm{a}$ \\
\hline \multirow{6}{*}{ C.m. } & 10 & $=72.0 \mathrm{a}$ & $145 \pm 16.3 \mathrm{a}$ & $278 \pm 22.4 \mathrm{a}$ & $312 \pm 30.7 \mathrm{a}$ & $256 \pm 28.1 \mathrm{a}$ \\
\hline & $10-20$ & $185 \pm 39.1 \mathrm{a}$ & $117 \pm 13.6 \mathrm{a}$ & $210 \pm 27.5 \mathrm{ab}$ & $292 \pm 46.7 \mathrm{a}$ & $236 \pm 20.0 \mathrm{ab}$ \\
\hline & $20-35$ & $206 \pm 22.8 \mathrm{a}$ & $103 \pm 20.7 \mathrm{a}$ & $206 \pm 43.1 \mathrm{ab}$ & $302 \pm 66.5 \mathrm{a}$ & $205 \pm 38.1 \mathrm{abc}$ \\
\hline & $35-50$ & $249 \pm 16.1 \mathrm{a}$ & $154 \pm 33.2 \mathrm{a}$ & $141 \pm 3.9 \mathrm{~b}$ & $256 \pm 37.2 \mathrm{a}$ & $163 \pm 32.1 \mathrm{bc}$ \\
\hline & $50-70$ & $215 \pm 29.4 \mathrm{a}$ & $153 \pm 35.4 \mathrm{a}$ & $148 \pm 23.2 b$ & $246 \pm 43.0 \mathrm{a}$ & $118 \pm 18.4 \mathrm{c}$ \\
\hline & $70-100$ & $178 \pm 13.6 \mathrm{a}$ & $167 \pm 35.4 \mathrm{a}$ & $145 \pm 23.6 b$ & $205 \pm 24.5 \mathrm{a}$ & $118 \pm 20.7 \mathrm{c}$ \\
\hline
\end{tabular}

Note: $a, b$ and c represents the results of multiple comparisons.

Table 3. The mean value comparison of $\mathrm{OC}$ and $\mathrm{SOC}_{\text {stork }}$ between three plant

\begin{tabular}{|c|c|c|c|c|c|c|c|}
\hline \multirow{2}{*}{$\begin{array}{l}\text { Mean } \\
\text { value }\end{array}$} & \multirow{2}{*}{$\begin{array}{c}\text { Soil } \\
\text { depth } \\
(\mathrm{cm})\end{array}$} & \multirow{2}{*}{$\begin{array}{l}\text { Plant } \\
\text { species }\end{array}$} & \multicolumn{5}{|c|}{ Planting years (a) } \\
\hline & & & 5 & 7 & 10 & 13 & 16 \\
\hline \multirow{6}{*}{$\mathrm{OC}$} & \multirow{3}{*}{$0-50$} & H.a. & 1.29 & 1.12 & 2.05 & 0.9 & 1.36 \\
\hline & & T.c. & 1.44 & 1.23 & 1.33 & 1.45 & 2 \\
\hline & & C.m. & 1.37 & 0.89 & 1.46 & 1.92 & 1.56 \\
\hline & \multirow{3}{*}{$0-200$} & H.a. & 1.2 & 1.04 & 1.8 & 0.72 & 1.09 \\
\hline & & T.c. & 1.55 & 1.17 & 1.08 & 1.42 & 1.71 \\
\hline & & C.m. & 1.3 & 1.03 & 1.18 & 1.69 & 1.2 \\
\hline \multirow{3}{*}{$\underset{\text { ork }}{\mathrm{SOC}_{\mathrm{st}}}$} & \multirow{3}{*}{$0-100$} & H.a. & 165.6 & 115.9 & 272.6 & 179.8 & 158.9 \\
\hline & & T.c. & 200.7 & 157.3 & 141.7 & 215.5 & 257 \\
\hline & & C.m. & 207.8 & 139.8 & 188 & 269 & 182.8 \\
\hline
\end{tabular}

The mean value of carbon content in $0-50 \mathrm{~cm}, 0-200$ $\mathrm{cm}$ and $\mathrm{OC}_{\text {stork }}$ in $0-100 \mathrm{~cm}$ were calculated in Table 3. The results showed that the soil organic carbon content under the influence of T.c. was bigger than H.a. ( except 10 years), and C.m. (except for 10 years and 13 years). This indicates that in early times during development of sandy soil, T.c. has more effects on accumulation of soil organic carbon in unit mass than H.a. and C.m.. As for

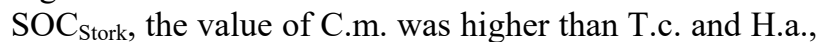
this indicates that the C.m. forest has more effects on accumulation of soil organic carbon in unit area than T.c. and H.a.

\subsection{Dynamic changes of passive OC with planting years}

Dynamic changes of OC with planting years can be seen from Fig.1. Only the total soil organic carbon stork in T.c. forest increased a little with year of plantation. This indicates the increase of planting years in T.c. forest have most influence on soil carbon sequestration.

With the increase of planting years, TOC, $\mathrm{OC}_{\mathrm{MIA}}$, $\mathrm{OC}_{\mathrm{HS}}, \mathrm{OC}_{\mathrm{HCl}}$ and $\mathrm{OC}_{\mathrm{NaClO}}$ content all increased. TOC, $\mathrm{OC}_{\mathrm{MIA}}, \mathrm{OC}_{\mathrm{HS}}$ increased year by year, and $\mathrm{OC}_{\mathrm{HCl}}$ and $\mathrm{OC}_{\mathrm{NaClO}}$ increased mainly in the first few years (except $\mathrm{OC}_{\mathrm{NaClO}}$ in T.c. forest and $\mathrm{OC}_{\mathrm{HCl}}$ in C.m. forest). Among them, $\mathrm{OC}_{\mathrm{HCl}}$ and $\mathrm{OC}_{\mathrm{NaClO}}$ content in H.a. forest increased faster in 5-7 years; $\mathrm{OC}_{\mathrm{NaClO}}$ in C.m. forest increased faster in 5-10 years; $\mathrm{OC}_{\mathrm{HCl}}$ in T.c. forest was increasing faster in 5 to 10 years. In addition to $\mathrm{OC}_{\mathrm{HCl}}$, other carbon fractions content of three plants increased significantly with the increase of planting years $(p<0.01)$. In terms of $\mathrm{OC}_{\mathrm{HCl}}$, the difference in H.a. forest is significant $(p<$ $0.05)$, the difference in T.c. forest is extremely significant $(p<0.01)$, while difference in C.m. forest is not obvious $(p>0.05)$.

The change scope of two physical fractions (TOC and $\left.\mathrm{OC}_{\mathrm{MIA}}\right)$ in three kinds of forest land are: in H.a., $0.735-2.607 \mathrm{~g} / \mathrm{kg}$ and $0.561-1.964 \mathrm{~g} / \mathrm{kg}$; in T.c., 0.96$3.55 \mathrm{~g} / \mathrm{kg}$ and $1.05-2.57 \mathrm{~g} / \mathrm{kg}$; in C.m., $1.25-2.19 \mathrm{~g} / \mathrm{kg}$ and $0.91-1.96 \mathrm{~g} / \mathrm{kg}$. The change scope of three chemical fractions $\left(\mathrm{OC}_{\mathrm{HS}}, \mathrm{OC}_{\mathrm{NaClO}}\right.$ and $\left.\mathrm{OC}_{\mathrm{HCl}}\right)$ are: in H.a., 0.136$1.064 \mathrm{~g} / \mathrm{kg}, 0.706-1.337 \mathrm{~g} / \mathrm{kg}$ and $0.267-0.470 \mathrm{~g} / \mathrm{kg}$; in T.c., $0.43-1.18 \mathrm{~g} / \mathrm{kg}, 0.68-1.27 \mathrm{~g} / \mathrm{kg}$ and $0.38-0.54 \mathrm{~g} / \mathrm{kg}$; in C.m., $0.46-84 \mathrm{~g} / \mathrm{kg}, 0.67-1.08 \mathrm{~g} / \mathrm{kg}$ and $0.28-0.32$ $\mathrm{g} / \mathrm{kg}$ 。

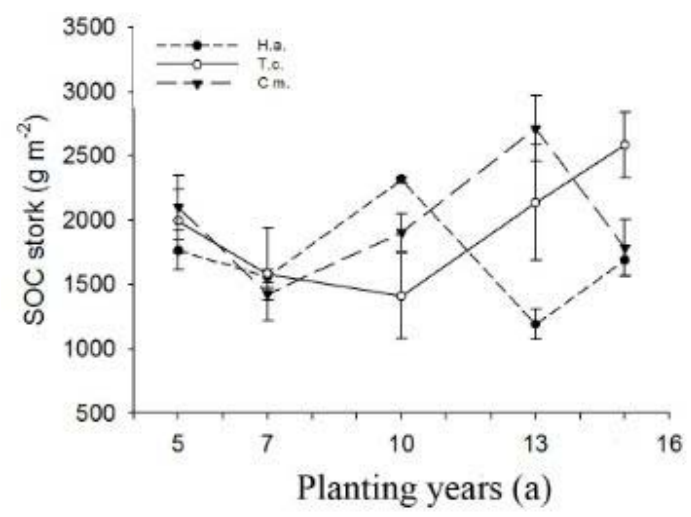



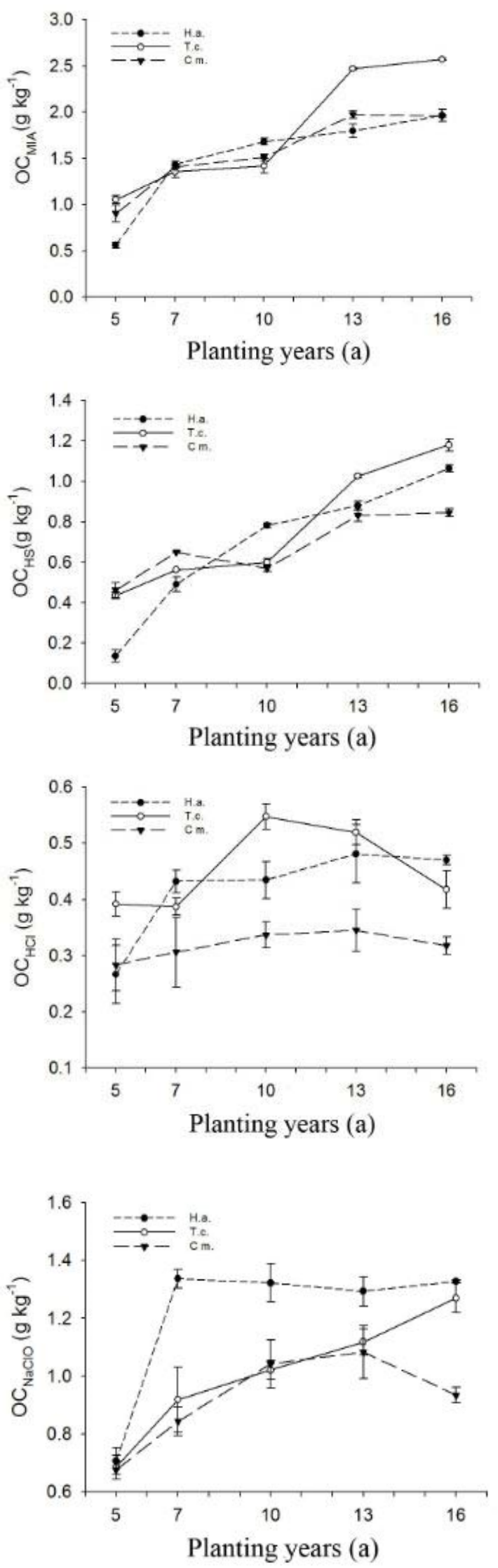

Fig.1 TOC: total organic carbon; OCMIA: organic carbon content micro-aggregate; OCHS: organic carbon in humus; $\mathrm{OC}_{\mathrm{NaClO}}$ : carbon resistance to oxidation; $\mathrm{OC}_{\mathrm{HCl}}$ : carbon resistance to acid hydrolysis.

\section{Conclusions}

Soil organic carbon content and stork changed with soil depth mainly in 0 to $50 \mathrm{~cm}$, and decreasing with depth increase. The T.c. forest plays the most important role in soil carbon accumulation in unit mass the C.m. plays the most in unit area. The space variation caused by C.m. is the biggest.

The passive organic carbon increased with planting years. $\mathrm{OC}_{\mathrm{MIA}}$ and $\mathrm{OC}_{\mathrm{HS}}$ increased years by years, while $\mathrm{OC}_{\mathrm{NaClO}}$ and $\mathrm{OC}_{\mathrm{HCl}}$ increased remarkably in first few years then had no obvious change. The humus organic carbon and aggregates organic carbon changed in line with total organic carbon with development years. Aggregation and resistance to oxidation played more important role than humification and resistance to hydrolysis in carbon sequestration during early soil development stage. With the planting years, the humification may play more important role.

\section{Acknowledgments}

This work was financially supported by National Natural Science Foundation of China (Grant No. 41571498).

\section{References}

1. J.Q. Lei, S.Y. Li, Chin. Sci. Bull 53, 190 (2008)

2. J.I. Hedges, G. Eglinton, P.G. Hatcher, Org. Chem 31, 945(2000)

3. J.S. Clemente, M.J. Simpson, Geoderma 192, 86 (2013)

4. M.H.B. Hayes, C. E. Clapp, Soil Sci 166, 723 (2001)

5. M. von Lützow, I. Kögel-Knabner, K. Ekschmitt, H. Flessa, G. Guggenberger, E. Matzner, B. Marschner, Soil Biol. Biochem 39, 2183 (2007)

6. E. Abakumov, O. Trubetskoj, Chem. Ecol 26, 59 (2010)

7. R. Smernik, J. Skjemstad, Biogeochem 92, 3 (2009)

8. E.S. Krull, C.W. Swanston, J.O. Skjemstad, J.A. McGowan, J. Geophys. Res 111, 4001 (2006)

9. E.A. Paul, S.J. Morris, R.T. Contant, A.F. Plante, Soil Sci. Am. J 70, 1023 (2006)

10. M. Helfrich, H. Flessa, R. Mikutta, A. Dreves, B. Ludwig, J. Soil Sci. 58, 1316 (2007)

11. Y.L. Zhang, C.X. Sun, Z.H. Duan, L.J. Chen, Z.J. Wu, X.H. Chen, A.M. Zhang, X.B. Liu, J.N. Wang, Spectrosc. Spect. Anal 30, 179 (2010)

12. W.B. Tan, L.P. Zhou, Chinese Sci. Bull 58, 1936 (2013)

13. M. Kaiser, R.H. Ellerbrock, Eur. J. Soil Sci 58, 1460 (2007)

14. A. Siregar, M. Kleber, R. Mikutta, R. Jahn, Eur. J. Soil Sci 56, 481 (2005)

15. E.A. Paul, R.F. Follett, S.W. Leavitt, A. Halvorson, G.A. Peterson, D.J. Lyon, Soil Sci. Soc. Am. J 61, 1058 (1997) 